\title{
Satisfaction with Democracy and Voter Turnout: A Temporal Perspective
}

\author{
Lawrence Ezrow \\ University of Essex \\ Department of Government \\ Wivenhoe Park \\ Colchester CO4 3SQ \\ United Kingdom \\ Georgios Xezonakis \\ University of Gothenburg \\ Department of Political Science \\ Quality of Government Institute \\ Sprängkullsgatan 19 \\ Sweden
}

Forthcoming, Party Politics

An earlier version was presented at the Workshop "How Do Electoral Systems and Party Systems Affect Satisfaction with Democracy?" held in London on February 1 ${ }^{\text {st }}, 2013$. The authors thank the anonymous reviewers, Jim Adams, André Blais, Ruth Dassonneville, Bob Goodin, Tim Hellwig, Simon Hix, Sara Hobolt, Annie Jones, and especially Mark Franklin for insightful comments on earlier drafts. 


\section{Bios}

Lawrence Ezrow is a Professor of Government at the University of Essex, UK. His research interests include political representation and parties' election strategies, and his articles have been published in the American Journal of Political Science, Journal of Politics, World Politics, and other journals.

Georgios Xezonakis is a Post Doctoral Research Fellow at Gothenburg University, Quality of Government Institute. His previous work appears in Comparative Political Studies, Electoral Studies, and other journals. 


\section{Satisfaction with Democracy and Voter Turnout: A Temporal Perspective}

Numerous studies conclude that countries in which citizens express higher levels of satisfaction with democracy also tend to display higher levels of voter turnout in national elections. Yet it is difficult to draw causal inferences from this positive cross-sectional relationship, because democracies feature many historical, cultural, and institutional differences that are not easily controlled for in cross-sectional comparisons. We apply an alternative, temporal, approach to this issue by asking the question: Are over-time declines (increases) in aggregate levels of satisfaction within democracies associated with increases (declines) in levels of voter turnout within these democracies? Our temporal analysis of this relationship in 12 democracies over the period 1976-2011 reveals a pattern that is the opposite of that suggested by previous crosssectional studies: namely, we find that over-time increases in citizens satisfaction with democracy are associated with significant decreases in voter turnout in national elections in these countries. 
We analyze voter turnout and its relationship to citizen satisfaction with democracy. Cross-national empirical studies on voter turnout suggest that levels of citizen satisfaction are linked to voter turnout (e.g., Franklin 2002, 2004; Clarke et al. 2004; Karp and Banducci 2008; Norris 2002; Anderson and Guillory 1997; for European Parliament elections, see Hobolt 2012). The logic that supports this observed relationship is that citizens who are more satisfied with democracy tend to be more politically engaged, and thus they are more likely to turn out to vote.

By contrast, there are theoretical considerations from the work of prominent scholars that contradict this conventional wisdom. While citizen satisfaction with democracy has long been tied to voter turnout, there is an equally strong consensus that dissatisfaction leads to higher levels of more direct unconventional forms of political participation (Gurr 1970). Furthermore, the distinction between unconventional forms of participation and conventional forms of political participation has blurred because citizens may seek change through multiple channels, from protest to voting (Norris 2002; see also Lijphart 1997). Dissatisfaction with democracy will generate demand for change in the electorate, which in turn motivates a higher level of turnout. In a nutshell, when explaining theories of conventional modes of political participation (i.e., voting), we should not ignore the factors that contribute to alternative forms of participation.

We address the relationship between satisfaction and turnout by asking the question: what is the nature of this relationship within countries across time? While cross-national empirical studies of turnout far outnumber longitudinal studies, it is problematic to assume that the cross-sectional relationships identified in these cross-national studies must be identical to the over-time relationships within countries (Franklin 2004: 14; see also Blais 2006).

\footnotetext{
${ }^{1}$ Relating to this argument, Mark Franklin (2004: 14) comments, “Are comparisons between countries equivalent to comparisons over time? Most scholars studying aggregate turnout levels have implicitly assumed that if they can identify factors that are associated with differences between countries, these same factors will account for why turnout changes over time. A country with low turnout is assumed to have the characteristics
} 
We address this point directly, and evaluate whether the relationship documented in cross-national studies between citizen satisfaction and turnout holds in longitudinal analyses (within countries over time). And the answer we provide is no: the cross-sectional relationship between satisfaction and turnout that we observe between countries is the opposite of the over-time relationships that that we observe within countries. When electorates report lower levels of satisfaction with democracy, voter turnout actually increases. This supports the argument that is developed in the next section that dissatisfaction generates demand for change in the electorate, which in turn mobilizes citizens to engage in, amongst other forms of participation, voting.

\section{Expectations about the Relationship between Satisfaction and Turnout}

Cross-national studies, based on the aggregate- and individual-levels, have documented a clear positive relationship between satisfaction and turnout (see, e.g., Birch 2010; Clarke et al. 2004; Franklin 2002, 2004; Grönlund and Setälä 2007; Hadjar and Beck 2010; Karp and Banducci 2008; Norris 2002; Powell 1986). It is nevertheless problematic to draw firm conclusions about causation. The reason is that it is difficult to control for the vast number of economic, cultural, and institutional differences across countries. Although this previous research is comprehensive in its approach (see, e.g., Franklin 2004), it is nearly impossible to control for all of the differences in political culture, historical experiences, and other factors that would affect levels of turnout. There are numerous (minor) institutional differences between countries that can affect turnout including how long in advance people must register to vote; how many hours polling stations stay open; whether elections take place on weekends or workdays; whether businesses are required to give employees time off to go vote; whether voters one country?" 
have to show photo identification; how convenient it is to travel to the local polling stations; what kinds of "turn out the vote" efforts political parties employ, and many additional factors. It is impossible to control for all these factors, which makes cross-sectional analysis, employed on its own, a problematic approach for analyzing the relationship between satisfaction and turnout. Over-time analyses may not perfectly control for all of these factors, but it seems to be an equally compelling approach to address the question.

Are over-time changes in aggregate levels of satisfaction within democracies associated with changes in levels of voter turnout within these democracies? This is an interesting empirical question because there are considerations that point in conflicting directions. The considerations that suggest that increases in satisfaction are associated with increases in voter turnout are raised in the cross-national studies reviewed above. If aggregate satisfaction with democracy decreases, this could indicate a lack of trust or fulfilment in the democratic process. That is, voting in elections may not be seen as an effective way of communicating one's preferences, and thus citizens should be less likely to turnout. Abstention could be viewed as a powerful signal for decreasing satisfaction (Grönlund and Setälä 2007). Additionally, to the degree that civic duty plays a role in turnout, declining levels of satisfaction with democracy may also be accompanied by declining levels of civic duty (Goodin and Roberts 1975), and subsequently by declining levels of turnout.

While the considerations discussed above suggest reasons why increases in aggregate levels of citizen satisfaction within democracies would lead to increases in levels of voter turnout in these democracies other considerations cast doubt on this widely accepted relationship. This argument unfolds in two steps: First, it is reasonable to associate dissatisfaction with a desire for change. And if citizens desire change, they will likely seek that change through multiple channels, including turning out for elections. 
While most literature stresses the role of dissatisfaction (e.g. "relative deprivation") in contributing to unconventional action (Gurr 1970), such a desire for change can equally affect conventional channels of political participation. Thus dissatisfaction should increase overall levels of political participation, including turnout in elections. Pippa Norris (2002), for example, links dissatisfaction (with public policy) to more peaceful forms of protest. With respect to voting, Norris $(2002,190-91)$ notes that, "early literature also drew an important line between "conventional" and "protest" forms of activism, and it is not clear whether this distinction remains appropriate today [...] new social movements may be adopting mixed action repertoires combining traditional acts such as voting and lobbying with a variety of alternative modes, such as internet networking, street protests, consumer boycotts, and direct action."

Scholars who are concerned about unequal democracy echo similar sentiments. They emphasize that some citizens have disproportionate influence in democracy because these citizens participate, not by voting, protesting, or engaging in only one particular activity. Rather, these citizens are likely to engage in multiple forms of participation. Arguing for compulsory voting, Lijphart (1997) comments, "it is especially the more advantaged citizens who engage in these intensive modes of participation - both conventional activities such as working in election campaigns, contacting government officials, contributing money to parties or candidates, and working informally in the community (Verba, Nie, and Kim 1978, 286-95) and unconventional activities like participation in demonstrations, boycotts, rent and tax strikes, occupying buildings, and blocking traffic (Marsh and Kaase 1979, 100, 112-26)" (Lijphart 1997, 1). If dissatisfaction increases levels of protest, it is also plausible that it will increase turnout.

In sum, there are conflicting theoretical arguments on this interesting empirical question. Several cross-national studies report a positive relationship between satisfaction and turnout. They argue that satisfaction signals engagement with the political process, which enhances turnout. On the other hand, there are compelling reasons to expect that dissatisfaction with 
democracy will generate demand for change in the electorate, which in turn motivates a higher level of turnout.

The discussion above motivates the following two hypotheses:

$H 1$ (The Satisfied Voter Hypothesis): Increases in satisfaction with democracy cause increases in voter turnout.

$H 2$ (The Dissatisfied Voter Hypothesis): Decreases in satisfaction with democracy cause increases in voter turnout.

\section{Data and Measurement}

To test whether citizen satisfaction increases or depresses voter turnout we develop longitudinal, cross-national measures of voter turnout and citizen satisfaction with democracy.

\section{The Dependent Variable: Voter Turnout}

To test this relationship it is necessary to measure voter turnout. Most comparative studies of turnout emphasize the importance of cross-national comparability of the measure. Given the longitudinal nature of this study, it is more crucial that our measure of turnout is consistent over time, within countries. The longitudinal measure of voter turnout derives from the publications of the Institute for Democracy and Electoral Assistance (IDEA). This dataset comprises regularly updated turnout figures for national elections dating back to $1945 .{ }^{2}$ In the models below the turnout figures are based on eligible voters (the potential number of voters that are of voting age). We also re-estimate the parameters for a model specification that measures voter turnout based on the total number of registered voters (Appendix 2, Model 3). In total we were able to collect turnout estimates that correspond with citizen satisfaction data, described below, from 1976 until 2011 in the 12 country sample.

\footnotetext{
${ }^{2}$ See http://www.idea.int/vt/index.cfm.
} 
The distributions of the turnout variable are presented in Figure 1 for the twelve countries in the analysis. The box plots represent turnout levels in each country, and there are several important patterns to which we point. In the period covered by our data Luxembourg, France, Portugal and Great Britain have the lowest turnout rates, and Denmark, Greece, Belgium and Italy have the highest rates. Ireland and Great Britain exhibit the most variation in turnout, and Denmark, Greece, and Belgium have stable turnout levels over time.

[Figure 1 here]

The Independent Variable: Satisfaction with Democracy

To test whether satisfaction relates to turnout, it is necessary to measure citizen satisfaction with democracy. The longitudinal measure of satisfaction with democracy derives from the Eurobarometer surveys from 1976 (the first year that the satisfaction with democracy item appears on the survey) until 2011. In these surveys, approximately 2000 respondents per country each year were asked to place themselves on a 4 point scale with the question: "On the whole, are you very satisfied, fairly satisfied, not very satisfied or not at all satisfied with the way democracy works in our country". Citizen satisfaction (i.e. satisfaction) is computed as the percentage of respondents who report that they are either "very" or "fairly" satisfied with democracy in a country election year. The wording of this question has remained consistent for the years of the investigation. Moreover, it is the same indicator that has been used in several related studies (see, e.g., Aarts and Thomassen 2008; Anderson and Guillory 1997).

The authors acknowledge scholarly reservations as to what this indicator actually measures (Fuchs, Guidorossi, and Svenson 1995; see also Cananche et al. 2001). A possible counterargument is that this question does not measure the legitimacy of the democratic system but rather support for the performance of the system (Linde and Ekman 2003; Norris 1999). With respect to this point, we note that there is not a firm consensus against its use 
(Blais and Gelineau 2007), and that supporters suggest that it remains a useful "hybrid"

indicator of important aspects of system support. Along these lines, they have commented that it remains "a reasonable (albeit imperfect) measure" (Anderson 2002: 10). Also, it continues to be employed as the standard indicator in a number of recent studies (Kumlin and Esaiasson 2012).

Nevertheless, we address these criticisms from two angles: First, we estimate the parameters of model specifications below in which several factors (e.g. economic growth and unemployment levels) are included that control for "performance" related variation in the dependent variable. Second, to address potential problems with measuring citizen satisfaction with democracy we conducted additional "errors-in-variables" analyses (in the supplementary materials), making different assumptions about the assumed reliability of the measure of citizen satisfaction. Each set of analyses described above continue to support the substantive conclusions that are reported below. ${ }^{3}$

The distributions of the satisfaction variable are presented in Figure 2 for the twelve countries in the analysis. The box plots represent reported satisfaction levels with democracy for the election years in each country, and they depict several important qualities of the satisfaction variable. In the period covered by our data, Italy is on average the country with the lowest citizen satisfaction, while Denmark and Luxembourg exhibit consistently high levels of satisfaction. Portugal, Germany and Spain exhibit the most variation in satisfaction

\footnotetext{
${ }^{3}$ While we analyze the direct effects of satisfaction with democracy on turnout, consideration of possible indirect effects -- relating to characteristics that may be correlated with satisfaction (in addition to performance indicators) which enhance turnout, such as political efficacy -- plausibly strengthens our conclusions. Suppose, for instance, that decreasing levels of citizens' satisfaction with democracy are associated with decreasing levels of political efficacy, either because satisfaction with democracy exerts a causal influence on efficacy or because both satisfaction and efficacy are both influenced by some unmeasured variable (such as political scandals or politicians' perceived responsiveness to citizens' concerns). Given that political efficacy has been positively linked with turnout in many previous studies (see, e.g., Miller and Listhaug 1990), we would then expect that decreasing levels of satisfaction with democracy would exert an indirect effect that depresses voter turnout, via its relationship to political efficacy. Thus, our empirical estimate that decreasing satisfaction with democracy is in fact associated with increased turnout represents a conservative estimate of the magnitude of this effect, because our estimate also captures any indirect effects associated with the link between democratic satisfaction and political efficacy that plausibly cut in the opposite direction. While we account for economic factors, the Eurobarometer survey does not provide adequate coverage of the efficacy item (or variables such as civic duty or trust in government) to address this point directly in the empirical analysis.
} 
across time, and Great Britain has rather stable satisfaction levels from one election year to another.

[Figure 2 here]

Figure 3 maps the time series of voter turnout and citizen satisfaction with democracy from 1976-2011 in the 12 countries in the study. One clear pattern that emerges is that turnout is in decline, which is consistent with previous research. ${ }^{4}$ The pattern is not as striking for satisfaction with democracy, although we notice a discernable upward trend in most countries. We also observe that inter-election declines (increases) in the percentage of "satisfied" citizens tend to be accompanied by increases (declines) in turnout. The most notable examples are France and Great Britain where the two series mirror each other. When citizen satisfaction decreases in between elections, levels of turnout rise, or converge on the satisfaction line. Conversely, when levels of satisfaction increase, levels of turnout diverge sharply from the satisfaction line. Similar patterns emerge if one examines the series for Germany, Netherlands, Ireland, Spain, and Denmark. The mirroring patterns in Figure 3 provide a prima facie case for the Dissatisfied Voter Hypothesis (H2), however the next section analyzes changes in voter turnout more systematically.

[Figure 3 here]

\section{Testing the Satisfied Voter Hypothesis and Dissatisfied Voter Hypothesis}

Recall that the Satisfied Voter Hypothesis predicts a positive relationship between (inter-election) changes in turnout and changes in citizen satisfaction, and the Dissatisfied Voter Hypothesis predicts a negative relationship. This latter expectation is at odds with predictions based on cross-national studies, where levels of satisfaction are linked to political engagement and turnout. We estimate parameters of "cross-national" OLS regression models

\footnotetext{
${ }^{4}$ We address the implications of trending for our conclusions in the sensitivity analysis section and Appendix 2 below.
} 
to evaluate whether this relationship between citizen satisfaction and turnout is present at the aggregate level. ${ }^{5}$ This "cross-national" specification is:

Turnout $(t)=\mathrm{B}_{0}+\mathrm{B}_{1}[$ Satisfaction $(t)]$

where Turnout $(t)$ is the level of voter turnout in a country at the current election $t$.

Satisfaction $(t)$ is the level of citizen satisfaction with a democracy in a country at the current election. And to address the Satisfied Voter Hypothesis and Dissatisfied Voter Hypothesis, our basic specification is:

$\Delta$ Turnout $(t)=\mathrm{B}_{0}+\mathrm{B}_{1}[\Delta$ Satisfaction $]$

$\mathrm{H} 1: \mathrm{B}_{1}>0$

$\mathrm{H} 2: \mathrm{B}_{1}<0$

In this model specification, we estimate "differences" in the variables of interest. A Dickey

Fuller test of stationarity suggests that both series (turnout and satisfaction with democracy)

are indeed non stationary. ${ }^{6}$ For turnout even the inclusion of the lagged dependent variable

does not seem to solve the stationarity problem. Differencing the two series is not only an

\footnotetext{
${ }^{5}$ One could argue that the theory is best tested at the aggregate level. To the extent that individual behavior is driven by expectations about the behavior of others, namely, under a collective action framework where social context matters for turnout (see, e.g., Franklin 2004: Chapter 2), a "climate" of citizen dissatisfaction may be conducive to turnout. The larger the pool of dissatisfied voters, the greater each dissatisfied voter's utility will be, because it increases the probability that the dissatisfied group as a whole will be successful at communicating its preferences in the next election. One implication of this theory is that certain types of parties gain or lose votes when satisfaction in the electorate changes. For example, decreased levels of satisfaction might produce increases in the vote totals for anti-system parties more than it depresses the vote totals for pro-system parties, or decreased satisfaction could increase the vote totals for opposition parties more than it depresses the vote totals for governing parties. We acknowledge an anonymous reviewer for raising this point.

Ideally, there would also be individual-level panel data to evaluate the hypotheses, and there are Swedish, German, British, Canadian, and New Zealand national election panel surveys available. However, most of these are not suitable for addressing the research question because the analysis requires individual-level measures -- pre- and post-election -- in two consecutive elections (i.e., a parallel analysis would require too many measures of the same individual than these surveys provide). Where enough measurements do exist, in the internet panel of the British Election Study, individual turnout is significantly over-reported (92.5\% in 2010 when the actual figure is $68 \%$ ), which suggests that it is unreliable. Additionally, there is not enough variation in changes in reported turnout for a parallel analysis at the individual-level.

${ }^{6}$ The presence of a unit root in both series cannot be rejected with probabilities of .73 and .41 respectively.
} 
econometric necessity but it also makes theoretical sense. Substantively, our theory posits that inter-election changes in one variable influence inter-election changes in the other.

Differencing the two series also deals with a problem of autocorrelation since a Wooldridge test of autocorrelation rejects the null hypothesis of no first order correlation with a probability of .003 . Accordingly, we difference additional variables that are subsequently included in the models (e.g. $\Delta$ Unemployment). If "levels" of variables are employed, instead of "differenced" variables, this does not change our substantive conclusions (Table 2 Column 7, and Table 3 Column 7). The inclusion of turnout in the previous election year (t-1) for the parameter estimates for one of the models (Table 1 Model 4) serves only as an additional control variable and a more stringent test of our hypotheses.

\section{Results for the Cross-National and Basic Specifications}

The analysis encompassed 90 election year measures of citizen satisfaction in Britain, Italy, Denmark, Belgium, France, Greece, Spain, Luxembourg, the Netherlands, Portugal, Ireland, and Germany in the period 1976-2011. ${ }^{7}$ These countries were selected based on the coverage of the Eurobarometer survey which consistently asks citizens to evaluate satisfaction with democracy with the same question dating back to the mid-1970s. For the crosssectional models, Models 1-2, we pool these observations and cluster standard errors by country. For Models 3-4, where the variables have been differenced, we estimate robust standard errors and (given our emphasis on within country variation) control for countryspecific effects. ${ }^{8}$

The parameter estimates for the cross-national specifications are presented in Columns 1-2 of Table 1. In the table, the coefficient estimating the effect of the satisfaction ( $t$ ) variable

\footnotetext{
${ }^{7}$ Satisfaction estimates for Germany, post-1990, were calculated by combining East and West German Eurobarometer samples, and weighting them relative to their population size.

${ }^{8}$ All of the models, except for Models 1-2 in Table 1, control for country-specific effects. We note that our substantive conclusions do not change if we do not control for these effects.
} 
upon the turnout $(t)$ variable is -0.14 and insignificant, however when we omit compulsory voting countries in Column 2 (see Blais 2000; Blais and Dobrzynska 1998; Franklin 2002; Powell 1982), the results conform to expectation, where the estimate on satisfaction $(t)$ is +.30 $(\mathrm{p}<.01) .{ }^{9}$ Cross-nationally, the analysis supports the finding that citizen satisfaction is associated with higher levels of turnout.

The parameter estimates for the basic model specifications are presented in Columns 3-4. The parameter estimates on the $\Delta$ satisfaction variable are negative and statistically significant $(B=-0.16, \mathrm{p}<.01 ; B=-.0 .17, \mathrm{p}<.01)$, which supports The Dissatisfied Voter Hypothesis $\left(\mathrm{H}_{2}\right)$ that increases in citizen satisfaction with democracy decreases voter turnout. This finding is labelled the The Dissatisfied Voter Result. These estimates are also substantively significant: in the bivariate model (Model 3), for example, a 10 percent increase in satisfaction is associated with a 1.6 percent decrease in turnout.

[Table 1 here]

Time between Elections, Competitiveness, Economic Conditions, and Party Polarization

While the results reported above provide evidence that voter turnout varies with changes in citizen satisfaction, there are several alternative explanations that would account for turnout variations, including: the time between elections; the competitiveness of elections; economic conditions; and party polarization. We explore each of these explanations in turn.

\section{Time between Elections and Competitiveness}

Intuitively, turnout should increase as the time between national elections increases (Franklin 2002, 2004; Norris 2002). For citizens, there are more years of policymaking at stake the larger the inter-election period. We measure time between elections in months. The

\footnotetext{
${ }^{9}$ To ease the substantive interpretation of our results, we have stratified the sample. When we estimate the model including an interaction between a compulsory voting dummy variable and satisfaction, our results remain unchanged.
} 
competitiveness of elections should also enhance turnout (Blais 2000; Blais and Carty 1990; Geys 2006; Powell 1986). The effects of competitive elections will appear on multiple levels of political competition. Voters are more likely to cast a deciding vote (even though this probability will remain very small). And various organizations -- like political parties and interest groups -- with a stake in the outcome will have greater incentives to mobilize their supporters. To measure competitiveness, we use the margin of victory, or the difference in vote percentage between the top two political parties.

We estimate the parameters of model specifications, relating to the time in between elections and the competitiveness of the election, in Columns 1-2 of Table 2. In Column 1, the parameter estimates on the $\Delta$ time between elections variable is positive and statistically significant which suggests that the time between elections contributes to voter turnout, i.e., as the number of months between elections increases (in relation to the time between elections in the previous inter-election period), voter turnout is expected to increase. If the estimate on the $\Delta$ competitiveness variable is negative, this suggests that as the difference between vote share between the first and second place candidates increases (i.e., the election is less competitive in comparison to the previous election), voter turnout decreases. The coefficient on the $\Delta$ competitiveness variable is negative and insignificant. More importantly, our results continue to provide evidence that decreases in aggregate satisfaction are associated with increases in turnout, i.e., these findings are consistent with the Dissatisfied Voter Hypothesis. In Columns 1-2 of Table 2, the coefficients on the variable $\Delta$ satisfaction are negative and statistically significant $(B=-0.20, \mathrm{p}<.01 ; B=-0.15, \mathrm{p}<.01)$.

\section{Economic Conditions}


Economic adversity tends to suppress electoral participation (Rosenstone 1982). ${ }^{10}$ $\triangle G D P$ (change in the GDP per capita from the year before the election to GDP per capita in the year of the election) ${ }^{11}$ and $\Delta$ unemployment are included as independent variables in Column 3 Table 2 because a number of studies have established a connection between system support and economic conditions (see, e.g., Norris 1999). If this is the case then the economy could be the factor that is driving citizen satisfaction. The theoretical justification for including these variables is based on the distinction between diffuse and specific support for the system (Easton 1975). According to Easton, individual support towards a system either manifests itself as diffuse support that is, support for democracy as a concept, an arrangement of political life or as an ideal, or as support towards the output that the system provides (specific support), that is support for the performance of the system across a number of areas (note that Easton recognizes the possibility that the specific support fuses with diffuse support in the long-term). Studies on support for institutions have stressed the importance that economic performance has for political trust and support (Clarke et al. 1993; Gilley 2006). Therefore, answers to the question "How satisfied are you with the way democracy works in your country?" will inevitably tap into perceptions of specific support and are likely to be driven, to an extent, by the general economic outlook and context in a given country at a given time. In order to adequately assess our hypothesis the model specification includes economic indicators on the right hand side of the equation. Measures of economic well-being, unemployment rates ( $\Delta$ unemployment), and Growth $(\Delta G D P)$ are not only theoretically but also empirically relevant as previous studies have shown. ${ }^{12}$

\footnotetext{
${ }^{10}$ Additionally, several scholars have reported that wealthy countries have higher levels of turnout (Norris 2002; Powell 1982; Blais and Dobrzynksa 1998).

11 When we estimate the parameters of the full model specification based on inter-election changes in growth $\left(\Delta G D P_{t}-\Delta G D P_{t-1}\right)$ the substantive results do not change.

${ }^{12}$ For measures of unemployment and GDP per capita, we rely on publications from the International Monetary Fund and the World Bank.
} 
Accordingly, we estimate the parameters of the economic conditions specification in

Column 3 of Table 2. The parameter estimates on the $\Delta G D P$ variable are negative and insignificant. The coefficient on the $\Delta$ unemployment variable is positive and statistically significant which suggests that turnout increases with higher levels of unemployment. Our results continue to provide evidence that a decrease in satisfaction is associated with an increase in turnout.

\section{Party Polarization}

Dalton (2008) and Steiner and Martin (2012) analyze turnout in the context of party system polarization. These authors argue that when party polarization decreases (or convergence increases), turnout drops because voters are "turned off" by a lack of ideological choice (see also Kittelson and Anderson 2011; Aarts and Wessels 2005). Accordingly, we control for changing levels of polarization, $\Delta$ polarization, on turnout. We rely on a measure of average party policy extremism that requires the ideological placements of parties, and the parties' vote shares. To measure party policy positions over time, we employ estimates from the Comparative Manifesto Project (CMP), which are reported in Budge et al. (2001) and Klingemann et al. (2006). ${ }^{13}$ In constructing a measure of party dispersion, scholars present different arguments about whether or not the parties' positions should be weighted by their size (see Alvarez and Nagler 2004). ${ }^{14}$ Both of these arguments appear reasonable, and, consequently, below we report empirical analyses for both weighted and unweighted measures of average party extremism. Appendix 1 presents the equations for calculating these measures.

\footnotetext{
${ }^{13}$ We recalibrated the CMP estimates to fit on 1-10 scale using the following equation: $($ CMP estimate $\times 9 / 200)+$ 5.5 .

${ }^{14}$ The argument for weighting party system dispersion by party size is that such weighting accounts for the fact that the small parties in some countries have virtually no political influence. The arguments for relying on an unweighted measure of party system dispersion are that a parties' policy influence does not necessarily correlate with vote (or seat) share. Additionally, small parties provide a vehicle through which voters can express their policy preferences, regardless of whether or not such parties significantly influence government policy outputs.
} 
We estimate the parameters of model specifications in Columns 4-5 of Table 2, including differenced versions of the Weighted and Unweighted Average Party Extremism variables (WPE and UPE), and we label this variable $\Delta$ polarization. ${ }^{15}$ The parameter estimates for the $\Delta$ polarization variable for Models 4-5 do not suggest that there is a systematic relationship between short-term changes in polarization and changes in turnout: one estimate is positive, and the other is negative, and each coefficient is insignificant. With respect to the relationship between citizen satisfaction and turnout, the negative and statistically significant estimates on the $\Delta$ satisfaction variable in Models 4-5 continue to provide evidence that decreases in aggregate satisfaction are associated with increases in turnout, i.e., these findings are consistent with the Dissatisfied Voter Hypothesis.

\section{Full Model Specification and a Model Based on "Levels” of Variables}

Column 6 in Table 2 reports the parameter estimates for a Fully-Specified Model, which controls for all of the variables in the analyses, including $\Delta$ time between elections, $\Delta$ competitiveness, $\triangle G D P, \Delta$ unemployment and $\Delta$ polarization. Also, although our variables are measured in terms of "changes", when corresponding model parameters are estimated in Column 7 of Table 2 including variables that are measured based on "levels" the results are unchanged.

[Table 2 here]

\section{Measuring Satisfaction Directly Preceding the Election}

The country election year measure of satisfaction is relied upon because it is based on very large samples of responses. However, it is possible that responses to the satisfaction question could be influenced by the outcomes of elections (Anderson and Guillory 1997). An

\footnotetext{
${ }^{15} \mathrm{We}$ also note that similar versions of this measure have been employed in several other studies of policy dispersion (see, e.g., Ezrow 2007; Singh 2009).
} 
alternative set of analyses were performed analyzing the Eurobarometer surveys (administered twice per year in the Spring and Autumn) that directly precede the focal election. Specifically, the parameters for the models in Table 2 were re-estimated using the Eurobarometer estimates of citizen satisfaction directly preceding the focal election. These estimates, which are reported in Table 3 (Models 1-7), continue to support our conclusions. ${ }^{16}$ In addition we conduct supplementary analyses with respect to compulsory voting countries, turnout based on registered voters, trending, outliers, electoral systems, party system size, and "errors-in-variables". ${ }^{17}$ The coefficient estimates for these model specifications on the $\Delta$ satisfaction variable continue to support The Dissatisfied Voter Hypothesis (H2).

[Table 3 here]

\section{Conclusion}

Voter turnout is widely viewed as an important indicator "of the health of a democracy" (Franklin 1999: 216; see also Powell 1986). The contribution of this study is to suggest that changes in turnout are also important. Our analysis of changes in turnout suggests that elections are - not only a vehicle through which citizens participate and demonstrate their engagement, but also - a mechanism through which dissatisfaction with democracy is expressed. If citizens become dissatisfied, and they do not express this dissatisfaction at the polls, this would signal concern for democracy. We find that electorates in established democracies do tend to mark increasing dissatisfaction with democracy by participating in national elections. By contrast, the finding that electorates participate less in

\footnotetext{
${ }^{16}$ The use of the previous Eurobarometer might not be ideal because the timing of the previous measurement still ranges from a few days to many months before the election. Additionally, the estimates of satisfaction are based on far fewer respondents.

${ }^{17} \mathrm{We}$ present these analyses in supplementary materials that are available on a website associated with the authors.
} 
elections when they are more satisfied with democracy is at odds with the traditional view that declining turnout should be seen negatively. ${ }^{18}$

There are several reasons why our findings are important. First, the outcome of interest is electoral participation, and so the general arguments that electoral participation is important for a functioning democracy are relevant here (see Lijphart 1997, 1999; see also Norris 2002). Discussing the importance of voting, Russell Dalton (2006, p. 42) states that "voting will remain an important aspect of democratic politics as much for its symbolic value as for its instrumental influence on policy. Voting is the one activity that binds the individual to the political system and legitimizes the rest of the democratic process."

Second, the study identifies an additional normative standard for measuring the health of democracy. As noted, scholars widely view voter turnout as a bellwether for assessing the health of democracy. The implication of this study is that change in turnout, and its subsequent effects, is also important. If, in the presence of increased dissatisfaction, we do not observe an increase in voting to communicate dissatisfaction, then this may also be a cause for concern. Put differently, if citizens abstain from voting when they are dissatisfied, this would signal complete disengagement from the electoral process. The ballot should not only be seen as an expression of satisfaction with democracy and institutions, but also as a safety mechanism for instances in which discontent arises.

Third, this study is important because it suggests that, in addition to viewing causality cross-nationally, scholars of turnout must consider a temporal approach in assessing these crucial relationships. There are a number of cross-national studies that report a positive relationship between satisfaction and turnout (Birch 2010; Grönlund and Setälä 2007; Hadjar and Beck 2011). We evaluate whether the cross-national relationship between citizen

\footnotetext{
${ }^{18}$ We thank an anonymous reviewer for encouraging us to further consider the implications of our findings.
} 
satisfaction and voter turnout directly translates into over-time relationships within a single country. We find that it does not.

The finding that declines (increases) in aggregate levels of satisfaction within democracies are associated with increases (declines) in levels of voter turnout within these democracies raises several interesting questions for future research. Our sample of democracies is limited in that we examine only established democracies. We might expect different relationships between changes in satisfaction and changes in turnout in different parts of the world. Newer democracies may not exhibit an increase in voting when aggregate levels of satisfaction decrease. As more longitudinal data becomes available, exploring additional variation in the relationship between changes in satisfaction and changes in turnout is an important next step.

Finally, it may be that to give greater consideration to longitudinal variation may unlock some of the puzzles in the cross-national voter turnout literature. For example, it is well documented that voter turnout is decreasing (e.g. Franklin 2004). This feature is surprising when we consider some of the cross-national conclusions about individual factors that contribute to turnout. Education and exposure to political information contributes to turnout, and these factors have been growing in developed democracies for the time period in which turnout is declining (Dalton 2002; see also Burden 2009). Indeed it is difficult to logically "add up" the contradictory findings that aggregate levels of information and education are increasing, while voter turnout is simultaneously decreasing. Our analysis suggests that turnout may be decreasing in established democracies where citizen satisfaction with democracy is increasing, which would be consistent with the finding that increasing aggregate levels of education (accompanied by increasing satisfaction) would not necessarily produce subsequent increases in voting. 
This study is the first to apply a temporal approach to parsing out the relationship between satisfaction and turnout. The temporal analyses support the opposite conclusion from the one that has been reached in previous cross-sectional studies, which suggests that it is important to distinguish between cross-national effects and longitudinal effects in future research on voter turnout. Finally, while we have identified an important aggregate pattern that enhances our understanding of changes in turnout, much more work needs to be done at the individual-level to fully explain our results. 


\section{Appendix 1. Measuring Average Party Extremism (Based on Ezrow 2007)}

The weighted measure of average party policy extremism (WPE) is defined as follows:

Weighted Party Extremism $=\sqrt{\sum_{j=1} \mathrm{VS}_{j}\left(\mathrm{P}_{j k}-\overline{\mathrm{P}}_{k}\right)^{2}}$

where,

$\overline{\mathrm{P}}_{k}=$ the weighted mean of all the parties' Left-Right ideological positions in country $k$.

$\mathrm{P}_{j k}=$ the ideological position of party $j$ in country $k$.

$\mathrm{VS}_{j}=$ Vote share for party $j$.

The alternative to weighing parties' positions by their vote shares is to weight all parties equally. This measure is the unweighted measure of the average party policy extremism (UPE), and it is constructed as follows:

Unweighted Party Extremism $=\sqrt{\sum_{j=1} \frac{\left(\mathrm{P}_{j k}-\overline{\mathrm{P}}_{k}\right)^{2}}{n}}$

where,

$\mathrm{n}=$ the number of parties included in the analysis for country $k$. 


\section{References}

Aarts, Kees, and Jacques Thomassen. 2008. "Satisfaction with Democracy: Do Institutions Matter?” Electoral Studies 27: 5-18.

Aarts, Kees, and Bernhard Wessels. 2005. "Electoral Turnout.” In: The European Voter. A Comparative Study of Modern Democracies, ed., Jacques Thomassen. Oxford: Oxford University Press, pp. 64-83.

Alvarez, R. Michael, and Jonathan Nagler. 2004. “Party System Compactness: Consequences and Measures." Political Analysis 12: 46-62.

Anderson, Christopher J. 2002. “Good Questions, Dubious Inferences, and Bad Solutions: Some Further Thoughts on Satisfaction with Democracy.” Binghamton University, Department of Political Science, Center on Democratic Performance Working Paper No. 116.

Anderson, Christopher J., and Christine A. Guillory. 1997. "Political Institutions and Satisfaction with Democracy: A Cross-National Analysis of Consensus and Majoritarian Systems.” American Political Science Review 91(1): 66-82.

Birch, Sarah. 2010. "Perceptions of Electoral Fairness and Voter Turnout.” Comparative Political Studies 43(12): 1601-1622.

Blais, André. 2000. To Vote or Not To Vote? The Merits and Limits of Rational Choice Theory. Pittsburgh: University of Pittsburgh Press.

Blais, André. 2006. "What Affects Voter Turnout?” Annual Review of Political Science 9: 111-25.

Blais, André and Ken Carty. 1990. "Does Proportional Representation Foster Voter Turnout?" European Journal of Political Research 18: 167-18.

Blais, André and Agnieszka Dobrzynska. 1998 “Turnout in Electoral Democracies.” European Journal of Political Research 33: 239-261. 
Blais, André, and François Gélineau. 2007. "Winning, Losing and Satisfaction with Democracy." Political Studies, 55(2): 425-441.

Budge, Ian, Hans-Dieter Klingemann, Andrea Volkens, Judith Bara, and Eric Tanenbaum. 2001. Mapping Policy Preferences: Estimates for Parties, Electors, and Governments 1945-1998. Oxford: Oxford University Press.

Burden, Barry. 2009. “The Dynamic Effects of Education on Voter Turnout.” Electoral Studies 28: 540-49.

Canache, Damarys, Jeffery Mondak, and Mitchell Seligson. 2001. "Meaning and Measurement in Cross-National Research on Satisfaction with Democracy." Public Opinion Quarterly 65: 506-528.

Clarke, Harold, and Alan C. Alcock. 1989. "National Elections and Political Attitudes: The Case of Political Efficacy." British Journal of Political Science 19 (4): 551-562.

Clarke, Harold, Dutt Nitish, and Allan Kornberg. 1993. "The Political Economy of Attitudes Toward polity and Society in Western European Democracies." Journal of Politics 55(4): 998-1021.

Clarke, Harold, David Sanders, Marianne Stewart, and Paul Whiteley. 2004. Political Choice in Britain. Oxford: Oxford University Press.

Dalton, Russell. 2006. Citizen Politics. Public Opinion and Political Parties in Advanced Industrial Democracies, $4^{\text {th }}$ ed. Chatham House.

Dalton, Russell. 2008. “The Quantity and the Quality of Party Systems: Party System Polarization, Its Measurement, and Its Consequences." Comparative Political Studies 41(7): 899-920.

Easton, David. 1975. “A Reassessment of the Concept of Political Support.” British Journal of Political Science 5: 435-57. 
Ezrow, Lawrence. 2007. "The Variance Matters: How Party Systems Represent the Preferences of Voters.” Journal of Politics 69(1): 182-192.

Franklin, Mark. 1999. "Electoral Engineering and Cross-National Turnout Differences: What Role for Compulsory Voting?” British Journal of Political Science 29: 205-16.

Franklin, Mark. 2002. “The Dynamics of Electoral Participation”. In: Elections and Voting in Global Perspective 2, eds. Laurence Leduc, Richard Niemi and Pippa Norris. Thousand Oaks CA: Sage.

Franklin, Mark. 2004. Voter Turnout and the Dynamics of Electoral Competition in Established Democracies Since 1945. New York: Cambridge University Press.

Fuchs, Dieter, Giovanna Guidorossi, and Pale Svensson. 1995. "Support for the Democratic System.” In: Citizens and the State, eds. Hans Dieter Klingemann and Dieter Fuchs. Oxford: Oxford University Press, pp. 323-353.

Geys, Benny. 2006. "Rational Theories of Voter Turnout: A Review.” Political Studies 4(1): $16-35$.

Gilley, Bruce. 2006. "The Meaning and Measure of Democratic Legitimacy." European Journal of Political Research 45(3): 499-525.

Goodin, Robert E., and Kevin W. S. Roberts. 1975. "The Ethical Voter.” American Political Science Review 69(3): 926-928.

Grönlund, Kimmo, and Mija Setälä. 2007. ’Political Trust, Satisfaction and Voter Turnout." Comparative European Politics 5: 400-422.

Hadjar, Andreas, and Michael Beck. 2011. "Who Does Not Particicapte in Elections in Europe and Why Is This.” European Societies 12(4): 521-542.

Hobolt, Sara B. 2012. "Citizen Satisfaction with Democracy in the European Union." Journal of Common Market Studies 50(1): 88-105. 
Karp, Jeffrey A., and Susan A. Banducci. 2008. "Political Efficacy and Participation in Twenty Seven Democracies: How Electoral Systems Shape Political Behavior.” British Journal of Political Science 38(2): 311-334.

Kittilson, Miki Caul, and Christopher J Anderson. 2011. "Electoral Supply and Voter Turnout." In Citizens, Context, and Choice: How Context Shapes Electoral Choices, eds., Russell J. Dalton and Christopher J. Anderson. Oxford: Oxford University Press. Klingemann, Hans-Dieter, Andrea Volkens, Judith Bara, Ian Budge and Michael D. McDonald. 2006. Mapping Policy Preferences II: Estimates for Parties, Electors and Governments in Central and Eastern Europe, European Union and OECD 1990-2003. Oxford: Oxford University Press.

Kumlin, Staffan, and Peter Esaiasson. 2012. "Scandal Fatigue? Scandal Elections and Satisfaction with Democracy in Western Europe.” British Journal of Political Science 42(2): 262-282.

Lijphart, Arend. 1997. “'Unequal Participation: Democracy’s Unresolved Dilemma.' American Political Science Review 91: 1-14.

Lijphart, Arend. 1999. Patterns of Democracy: Government Forms and Performance in Thirty-Six Countries. New Haven: Yale University Press.

Linde, Jonas and Joackim Ekman. 2003. "Satisfaction with Democracy: A Note on a Frequently Used Indicator in Comparative Politics.” European Journal of Political Research 42 (3): 391-408.

Marsh, Alan, and Max Kaase. 1979. "Background of Political Action.” In Political Action: Mass Participation in Five Western Democracies, eds., Samuel H. Barnes and Max Kaase. Beverley Hills, CA: Sage. 
Miller, Arthur, and Ola Listhaug. 1990. "Political Parties and Confidence in Government: A Comparison of Norway, Sweden, and the United States.” British Journal of Political Science 29: 357-386.

Norris Pippa. 1999. Critical Citizens: Global Support for Democratic Government. Oxford: Oxford University Press.

Norris, Pippa. 2002. Democratic Phoenix: Reinventing Political Activism. Cambridge: Cambridge University Press.

Powell, G. Bingham. 1982. Contemporary Democracies: Participation, Stability and Violence. Cambridge: Harvard University Press.

Powell, G. Bingham. 1986. "American Voter turnout in Comparative Perspective." American Political Science Review 80(1): 17-43.

Rosenstone, Steven. 1982. "Economic Adversity and Voter Turnout." American Journal of Political Science 26(1): 25-46.

Singh, Shane. 2009. "Party-Voter Correspondence and Political Dimensionality." Paper presented at the annual meeting of the Midwest Political Science Association.

Steiner, Nils D., and Christian W. Martin. 2012. "Economic Integration, Party Polarization, and Electoral Turnout: Testing for a Causal Chain.” West European Politics 35(2): 238-65.

Verba, Sidney, Norman H. Nye, and Jae-On Kim. 1978. Participation and Political Equality: A Seven-Nation Comparison. Cambridge: Cambridge University Press. 
Figure 1. Distribution of Turnout

Turnout in 12 Countries

1976-2011

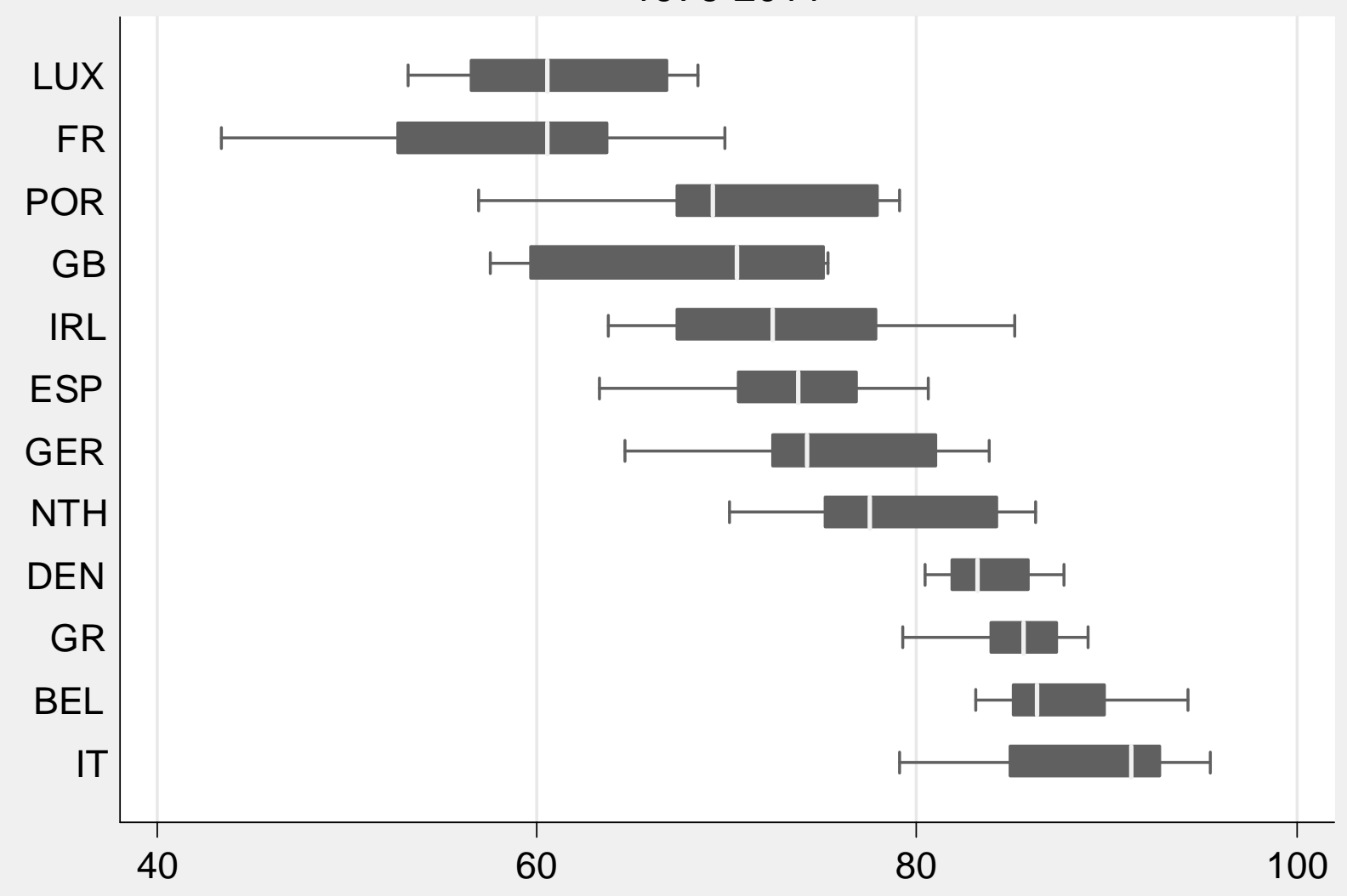

Notes. The boxes plot the percentages of election turnout in all the election years in each country between 1976 and 2011. There is an average of 6 election years in each country with a maximum of 13 (Denmark) and a minimum of 8 (France, UK, Spain and Portugal) in the time-period covered. The lines inside the boxes represent median values. The boxes depict the interquartile range of observations within each country, and the tips of the "whiskers" are the minimum and maximum values up to 1.5 times the interquartile range. 
Figure 2. Distribution of Satisfaction

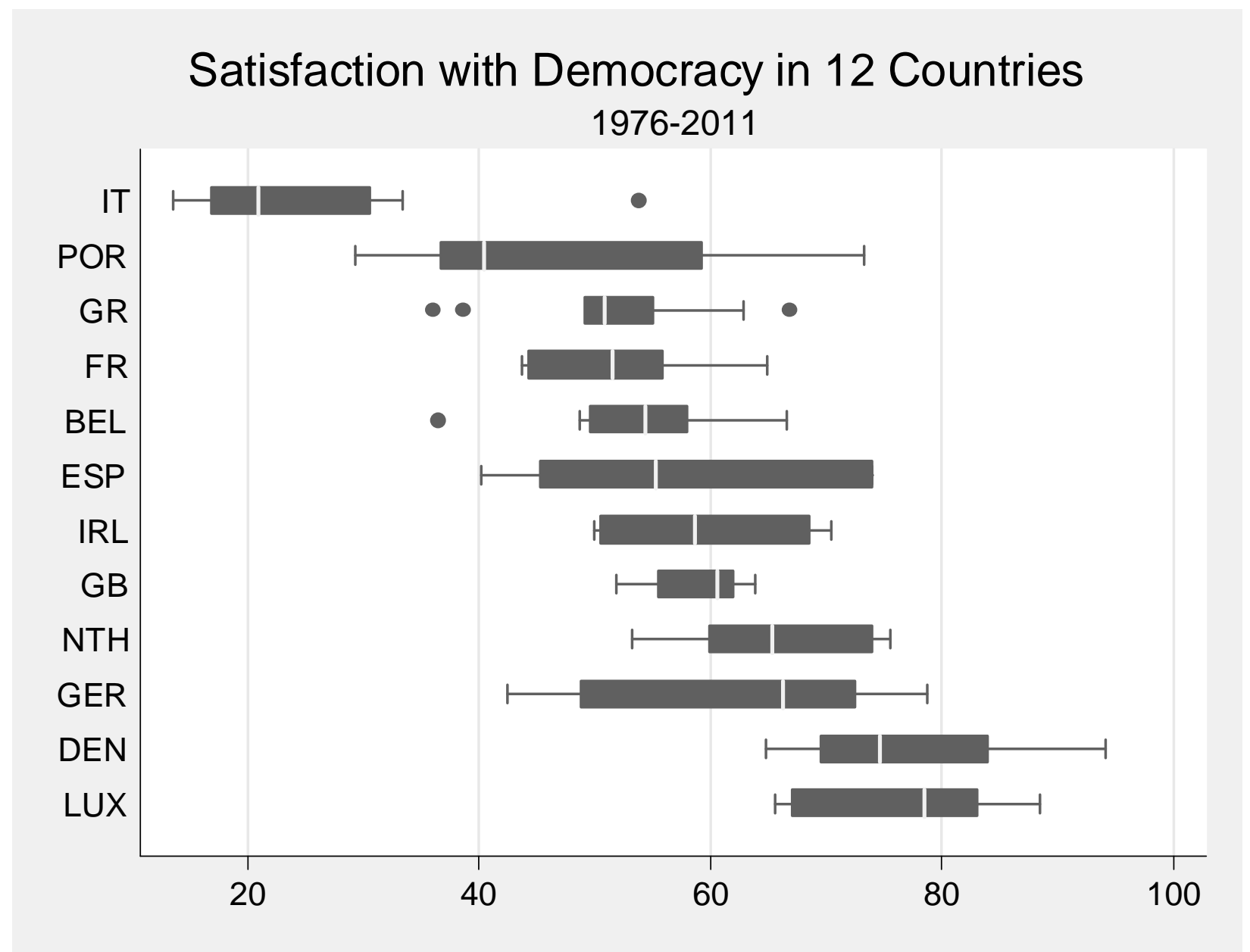

Notes. The boxes plot the percentages of those "very" and "fairly" satisfied with democracy in all the election years in each country between 1976 and 2011. There is an average of 6 election years in each country with a maximum of 13 (Denmark) and a minimum of 8 (France, UK, Spain, and Portugal) in the time-period covered. The lines inside the boxes represent median values. The boxes depict the interquartile range of observations within each country, and the tips of the "whiskers" are the minimum and maximum values up to 1.5 times the interquartile range (and the dots represent outliers). 
Figure 3. Citizen Satisfaction with Democracy and Voter Turnout, 1976-2011
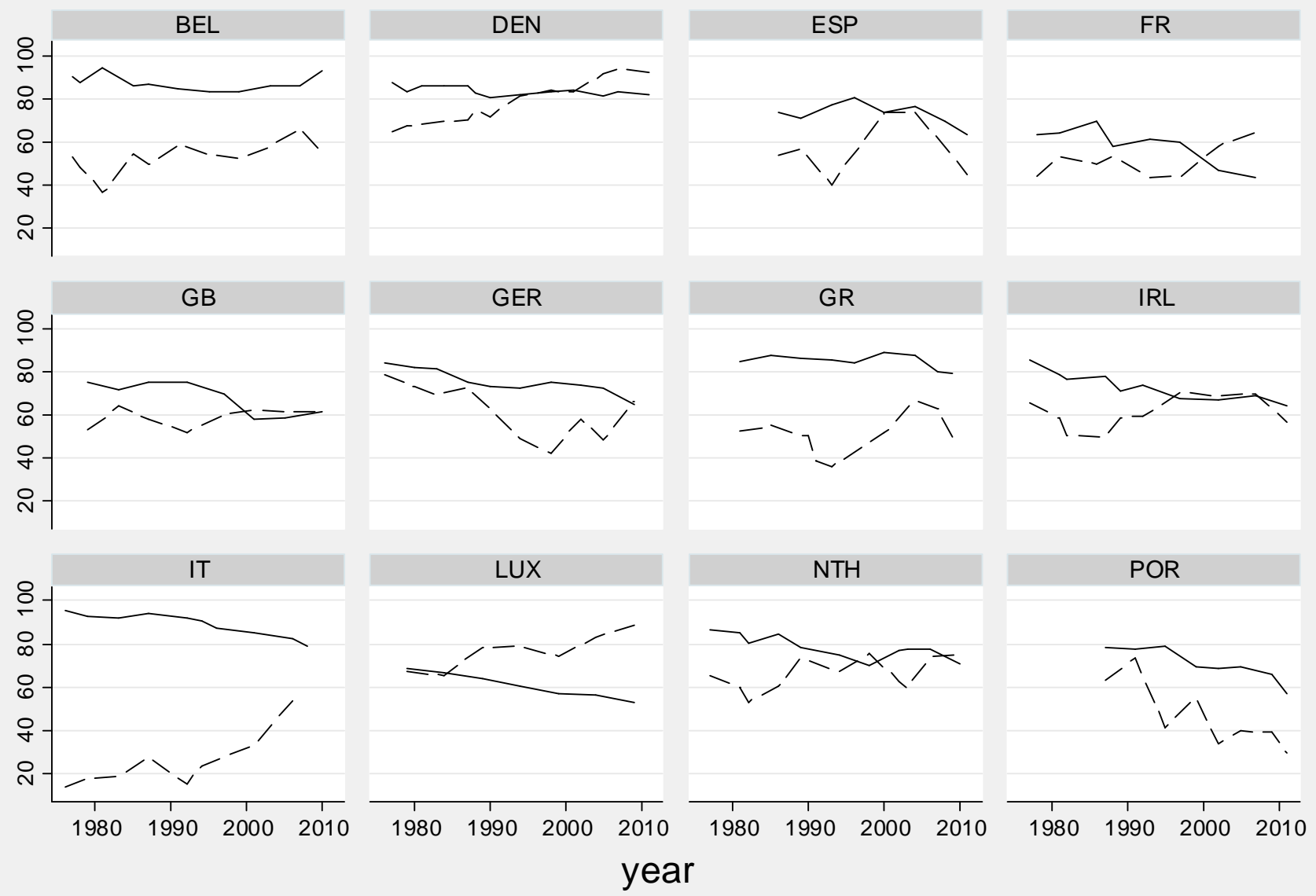

Turnout

\section{Satisfaction with Democracy}

Note: The 0-100 scale on the $y$-axis is the same scale for percentages of turnout and citizens that report that they are satisfied with democracy. Turnout is based on the percentage of Voting Age Population. Satisfaction with Democracy is calculated as the percentage of respondents that reported that they were "very" or "fairly" satisfied with democracy. 


\section{Table 1. Bivariate and Multivariate Analyses of Turnout}

\begin{tabular}{|c|c|c|c|c|}
\hline & \multicolumn{2}{|c|}{$\frac{\text { Cross-National }}{\text { Models }}$} & \multicolumn{2}{|c|}{ Differencing Variables } \\
\hline & $\begin{array}{c}\text { All } \\
\text { Countries } \\
(1)\end{array}$ & $\begin{array}{c}\text { Omit } \\
\text { comp. } \\
\text { voting } \\
(2)\end{array}$ & $\begin{array}{c}\text { Bivariate } \\
\text { (3) }\end{array}$ & $\begin{array}{c}\text { Including } \\
\text { Lag DV } \\
\text { (4) }\end{array}$ \\
\hline Satisfaction ( $($ ) & $\begin{array}{l}-0.14 \\
(0.16)\end{array}$ & $\begin{array}{c}0.30^{* * *} \\
(0.07)\end{array}$ & & \\
\hline$\triangle$ Satisfaction & & & $\begin{array}{c}-0.16 * * * \\
(0.05)\end{array}$ & $\begin{array}{c}-0.17 * * * \\
(0.05)\end{array}$ \\
\hline$\Delta$ Turnout (t-1) & & & & $\begin{array}{l}-0.13 \\
(0.08)\end{array}$ \\
\hline Intercept & $\begin{array}{c}84.76 * * * \\
(10.25)\end{array}$ & $\begin{array}{c}54.96 * * * \\
(5.20)\end{array}$ & $\begin{array}{c}-1.43 * * * \\
(0.38)\end{array}$ & $\begin{array}{c}-1.52 * * * \\
(0.14)\end{array}$ \\
\hline $\mathrm{N}$ & 107 & 73 & 88 & 75 \\
\hline $\begin{array}{l}R^{2} \\
\text { Number of } \\
\text { Countries }\end{array}$ & 0.05 & 0.19 & $\begin{array}{c}0.12 \\
12\end{array}$ & $\begin{array}{c}0.19 \\
12\end{array}$ \\
\hline
\end{tabular}

Notes. $* \mathrm{p}<.10, * * \mathrm{p}<.05, * * * \mathrm{p}<.01$, two-tailed test; Robust standard errors are in parentheses. The observations in Columns 1-2 are pooled and the standard errors are clustered by country. The compulsory voting countries that are omitted in the second model are Belgium, Italy, Greece, and Luxemburg. The models in Columns 3-4 control for country-specific fixed effects, and the dependent variable is $\Delta$ Turnout. Differenced variables are based on changes between elections. 
Table 2. Multivariate Analyses of Turnout: Competitiveness, Economic Conditions, Polarization, and Full Model Specifications

\begin{tabular}{|c|c|c|c|c|c|c|c|}
\hline & $\begin{array}{c}\text { Time } \\
\text { between }\end{array}$ & Competitiveness & $\begin{array}{l}\text { Economic } \\
\text { Conditions } \\
\end{array}$ & WPE & UPE & Full & Levels \\
\hline$\triangle$ Satisfaction & $\begin{array}{c}-0.20 * * * \\
(0.05)\end{array}$ & $\begin{array}{c}-0.15 * * * \\
(0.04)\end{array}$ & $\begin{array}{c}-0.11 * * \\
(0.05)\end{array}$ & $\begin{array}{c}-0.17 * * * \\
(0.04)\end{array}$ & $\begin{array}{c}-0.18 * * * \\
(0.05)\end{array}$ & $\begin{array}{c}-0.14 * * \\
(0.05)\end{array}$ & $\begin{array}{l}-0.17 * \\
(0.08)\end{array}$ \\
\hline$\Delta$ Time between elections & $\begin{array}{c}0.08 * * \\
(0.03)\end{array}$ & & & & & $\begin{array}{c}0.09 * * \\
(0.03)\end{array}$ & $\begin{array}{l}-0.04 * \\
(.0 .02)\end{array}$ \\
\hline$\triangle$ Competitiveness & & $\begin{array}{l}-0.09 \\
(0.05)\end{array}$ & & & & $\begin{array}{l}-0.08 \\
(0.06)\end{array}$ & $\begin{array}{l}-0.07 \\
(0.12)\end{array}$ \\
\hline$\triangle G D P$ & & & $\begin{array}{l}-0.10 \\
(0.14)\end{array}$ & & & $\begin{array}{l}-0.07 \\
(0.17)\end{array}$ & $\begin{array}{c}.03 \\
(0.19)\end{array}$ \\
\hline UUnemployment & & & $\begin{array}{l}0.73 * * \\
(0.27)\end{array}$ & & & $\begin{array}{c}0.60 * * \\
(0.26)\end{array}$ & $\begin{array}{c}-.03 \\
(0.23)\end{array}$ \\
\hline APolarization & & & & $\begin{array}{c}1.13 \\
(1.81)\end{array}$ & $\begin{array}{l}-1.11 \\
(1.57)\end{array}$ & $\begin{array}{c}2.05 \\
(1.59)\end{array}$ & $\begin{array}{l}4.56^{*} \\
(2.19)\end{array}$ \\
\hline Turnout $t-1$ & & & & & & & $\begin{array}{l}.59 * * * \\
(0.08)\end{array}$ \\
\hline Constant & $\begin{array}{c}-1.35 * * * \\
(0.05)\end{array}$ & $\begin{array}{c}-1.49 * * * \\
(0.04)\end{array}$ & $\begin{array}{c}-0.73 * * \\
(0.30)\end{array}$ & $\begin{array}{c}-1.37 * * * \\
(0.03)\end{array}$ & $\begin{array}{c}-1.33 * * * \\
(0.04)\end{array}$ & $\begin{array}{c}-0.88^{* *} \\
(0.37)\end{array}$ & $\begin{array}{c}34.98 * * * \\
(9.24)\end{array}$ \\
\hline Observations & 88 & 88 & 64 & 85 & 85 & 61 & 73 \\
\hline R-squared & 0.23 & 0.16 & 0.33 & 0.17 & 0.17 & 0.47 & .55 \\
\hline Number of Countries & 12 & 12 & 12 & 12 & 12 & 12 & 12 \\
\hline
\end{tabular}

Notes. ${ }^{*} \mathrm{p}<.10,{ }^{* *} \mathrm{p}<.05, * * * \mathrm{p}<.01$, two-tailed test; Dependent variable is $\Delta$ Turnout. All models control for country-specific fixed effects. Robust standard errors clustered by country are in parentheses. "WPE" and "UPE" refer to the weighted and unweighted measures of average party extremism described in Appendix 1. Differenced variables are based on changes between elections except for $\triangle G D P$ which is based on the difference in GDP from the year before the election to the year of the election (see footnote 11). Weighted Average Party Extremism is the measure used in the full model specification. All of the variables in the "Levels" model specification in Column 7 are measured based on levels (instead of differences) of the variables. "Turnout $t-l$ " is the proportion of eligible voters that voted in the previous election. 


\section{Table 3. Multivariate Analyses of Turnout, Based on Eurobarometer Surveys Immediately Prior to National Elections}

\begin{tabular}{|c|c|c|c|c|c|c|c|}
\hline & $\begin{array}{c}\text { Time } \\
\text { between }\end{array}$ & Competitiveness & $\begin{array}{l}\text { Economic } \\
\text { Conditions }\end{array}$ & WPE & UPE & Full & Levels \\
\hline ¿Satisfaction & $\begin{array}{c}-0.07 * \\
(0.04)\end{array}$ & $\begin{array}{c}-0.07 * * \\
(0.03)\end{array}$ & $\begin{array}{l}-0.05^{*} \\
(0.02)\end{array}$ & $\begin{array}{c}-0.07 * * \\
(0.03)\end{array}$ & $\begin{array}{l}-0.08 * \\
(0.04)\end{array}$ & $\begin{array}{c}-0.04 * * \\
(0.02)\end{array}$ & $\begin{array}{c}-0.07 * * \\
(0.02)\end{array}$ \\
\hline$\Delta$ Time between elections & $\begin{array}{l}0.04 * \\
(0.02)\end{array}$ & & & & & $\begin{array}{c}0.07 * * \\
(0.02)\end{array}$ & $\begin{array}{c}0.01 \\
(0.02)\end{array}$ \\
\hline$\triangle$ Competitiveness & & $\begin{array}{c}-0.17 * * \\
(0.06)\end{array}$ & & & & $\begin{array}{l}-0.12 * \\
(0.06)\end{array}$ & $\begin{array}{l}-0.14 \\
(0.11)\end{array}$ \\
\hline$\triangle G D P$ & & & $\begin{array}{c}-0.01 \\
(0.15)\end{array}$ & & & $\begin{array}{l}-0.05 \\
(0.21)\end{array}$ & $\begin{array}{c}0.09 \\
(0.21)\end{array}$ \\
\hline$\Delta$ Unemployment & & & $\begin{array}{c}0.85^{* * *} \\
(0.21)\end{array}$ & & & $\begin{array}{l}0.71 * * \\
(0.23)\end{array}$ & $\begin{array}{c}0.24 \\
(0.19)\end{array}$ \\
\hline$\triangle$ Polarization & & & & $\begin{array}{c}2.29 \\
(1.47)\end{array}$ & $\begin{array}{c}0.47 \\
(1.77)\end{array}$ & $\begin{array}{c}2.17 \\
(1.31)\end{array}$ & $\begin{array}{l}4.29 * * \\
(1.79)\end{array}$ \\
\hline Turnout t-1 & & & & & & & $\begin{array}{c}0.65^{* * * *} \\
(0.10)\end{array}$ \\
\hline Constant & $\begin{array}{c}-1.53 * * * \\
(0.06)\end{array}$ & $\begin{array}{c}-1.62 * * * \\
(0.04)\end{array}$ & $\begin{array}{c}-0.93 * * \\
(0.30)\end{array}$ & $\begin{array}{c}-1.36 * * * \\
(0.06)\end{array}$ & $\begin{array}{c}-1.40 * * * \\
(0.06)\end{array}$ & $\begin{array}{c}-0.93 * * \\
(0.39)\end{array}$ & $\begin{array}{c}20.15^{* * *} \\
(8.08)\end{array}$ \\
\hline Observations & 96 & 96 & 72 & 92 & 92 & 69 & 77 \\
\hline R-squared & 0.09 & 0.14 & 0.30 & 0.13 & 0.09 & 0.43 & .57 \\
\hline Number of Countries & 12 & 12 & 12 & 12 & 12 & 12 & 12 \\
\hline
\end{tabular}

Notes. ${ }^{*} \mathrm{p}<.10,{ }^{* *} \mathrm{p}<.05,{ }^{* * *} \mathrm{p}<.01$, two-tailed test; Dependent variable is $\Delta$ Turnout. All models include country-specific fixed effects. Robust standard errors are in parentheses. "WPE" and "UPE" refer to the weighted and unweighted measures of average party extremism described in Appendix 1. Weighted Average Party Extremism is the measure used in the full model specification. All of the variables in the "levels" model specification in Column 7 are measured based on levels (instead of differences) of the variables. "Turnout $t-1$ " is the proportion of eligible voters that voted in the previous election. 